\title{
Reaksi Pasar Modal Terhadap Aksi Penolakan Mahasiswa Terkait Rancangan Kitan Undang-Undang Hukum Pidana (Event Study Pada Bursa Efek Indonesia)
}

\author{
Santy Aji Sitohang ${ }^{1}$, Wie She Wudjud ${ }^{2}$ \\ Universitas Darma Agung, Medan ${ }^{1}$, STIE PMCI, Medan ${ }^{2}$ \\ santysitohang90@gmail.com, Wieshi_Wudjud@yahoo.com
}

\begin{abstract}
Abstrak: Mahasiswa menggelar demonstrasi untuk memprotes sejumlah undang-undang yang dinilai kontroversial. Aksi demonstrasi ini memberikan sentimen negatif terhadap kondisi pasar modal yang ditandai keluarnya dana asing dari bursa saham dan kinerja pasar modal berada di zona merah. Tujuan dari penelitian ini untuk mengetahui bagaimana reaksi pasar modal sebelum dan sesudah terjadinya aksi demontrasi mahasiswa. Reaksi pasar modal diukur dari aliran modal asing (net sell atau net buy), Indeks Harga Saham Gabungan dan Indeks LQ45 di Bursa Efek Indonesia. Jenis penelitian ini adalah event study dengan periode pengamatan selama 21 hari perdagangan yaitu 10 hari perdagangan sebelum peristiwa, 1 hari perdagangan pada saat peristiwa dan 10 hari perdagangan setelah peristiwa. Metode analisis data yaitu uji statistik deskriptif, uji normalitas dan uji Paired Sample t-test. Hasil penelitian menunjukan : (1) Tidak terdapat perbedaan yang signifikan pada Aliran Modal Asing di Bursa Efek Indonesia baik sebelum dan sesudah aksi demonstrasi mahasiswa (2) Terdapat perbedaan yang signifikan pada Indeks Harga Saham Gabungan di Bursa Efek Indonesia sebelum dan sesudah aksi demonstrai mahasiswa (3) Terdapat perbedaan yang signifikan pada Indeks LQ45 di Bursa Efek Indonesia sebelum dan sesudah aksi demonstrasi mahasiswa.
\end{abstract}

Kata Kunci : Aliran Modal Asing, Indeks Harga Saham Gabungan, Indeks LQ45 


\section{Pendahuluan}

Kondisi pasar modal Indonesia sepanjang periode September 2019 mendapat tekanan yang beruntun baik dari isu global maupun domestik. Isu global berasal dari masalah perang dagang Amerika Serikat dan China yang terus berlanjut. Sementara masalah domestik berasal dari adanya gelombang aksi unjuk rasa mahasiswa yang menolak RUU KUHP dan Revisi UU KPK. Aksi demonstrasi merupakan hal yang biasa dan wajar terjadi bagi negara yang menganut demokrasi seperti Indonesia. Meskipun demonstrasi perlu dihargai, namun aksi demonstrasi di Indonesia mempunyai track record yang buruk karena selalu diwarnai tindakan anarkis dan demostran sering meluapkan kemarahannya dengan merusak fasilitas umum. Demikian pula halnya dengan gelombang aksi mahasiswa yang terjadi di Jakarta dan beberapa daerah lainnya yang berujung pada kericuhan dan perusakan sejumlah fasilitas umum.

Aksi demonstrasi yang dilakukan kalangan mahasiswa nyatanya telah menimbulkan sentimen negatif di pasar keuangan. Hal ini terefleksi pada penurunan Indeks harga Saham Gabungan dan jatuhnya nilai tukar Rupiah. Aksi mahasiswa ini ternyata terus berlanjut sehingga menimbulkan rasa takut dan keragu-raguan bagi investor untuk menanamkan modalnya di Indonesia. Pelaku pasar mulai bertanya-tanya, apakah unjuk rasa ini murni mengkritik kinerja pemerintah atau sengaja dimanfaatkan oleh pihak tertentu untuk menjatuhkan pemerintah. Rasa ketakutan dari investor ini terjadi karena arah dan tujuan dari aksi demonstrasi sudah mulai melenceng karena DPR dan Presiden sudah sepakat memenuhi sebagian dan tuntutan mahasiswa dengan menunda pengesahan RUU. Itikat baik Presiden yang mengundang mahasiswa untuk berdialog dengan perwakilan Badan Eksekutif Mahasiswa (BEM) malah ditolak sebagian mahasiswa.

Gelombang unjuk rasa ini yang menjalar ke mana-mana menunjukkan ketidakpastian stabilitas sosial-politik di Indonesia. Perlu diketahui bahwa ketidakpastian sosial-politik merupakan musuh utama dari pelaku pasar atau investor. Bisnis hanya tumbuh dalam kondisi sosial politik yang stabil karena semua bisnis berjalan berdasarkan perhitungan risiko yang mungkin terjadi. Kepercayaan investor untuk menanamkan modalnya di Indonesia mulai menurun seiring banyaknya peristiwa yang terjadi di Indonesia yang mendapat perhatian dunia seperti masalah demonstrasi penolakan hasil pilpres, masalah Papua, kebakaran hutan dan lahan serta penolakan RUU KUHP dan Revisi UU KPK yang dilakukan oleh mahasiswa. Dampak dari aksi demonstrasi yang terjadi telah terefleksi pada penurunan nilai tukar rupiah, Indeks Harga Saham Gabungan yang semakin terpuruk dan banyaknya aliran modal asing yang kelauar dari pasar keuangan Indonesia.

Berdasarkan uraian tersebut, maka tujuan dari penelitian ini adalah untuk :

1. Mengetahui apakah terdapat perbedaan yang signifikan pada Aliran Modal Asing di Bursa Efek Indonesia sebelum dan sesudah terjadinya aksi penolakan mahasiswa terhadap RUU KUHP dan Revisi UU KPK.

2. Mengetahui apakah terdapat perbedaan yang signifikan pada Indeks Harga Saham Gabungan di Bursa Efek Indonesia sebelum dan sesudah terjadinya aksi penolakan mahasiswa terhadap RUU KUHP dan Revisi UU KPK.

3. Mengetahui apakah terdapat perbedaan yang signifikan pada Indeks LQ45 di Bursa Efek Indonesia sebelum dan sesudah terjadinya aksi penolakan mahasiswa terhadap RUU KUHP dan Revisi UU KPK.

\section{Kerangka Teoritis dan Pengembangan Hipotesis}

\subsection{Aliran Modal Asing}

Kondisi pasar saham Indonesia cenderung mengikuti kondisi global dan domestik. Ketika kondisi global dan domestik bagus maka saham akan naik, sebaliknya jika kondisi global dan domestik memburuk maka saham akan ikut-ikutan memburuk. Kondisi global dan domestik ini bukan berasal dari faktor fundamental melainkan keyakinan investor. Ketika pelaku pasar terutama investor asing yakin bahwa kondisi akan lebih baik maka investor akan banyak membeli saham dan harga saham akan naik demikian sebaliknya. Keyakinan investor asing dalam berinvestasi diukur dari angka Net Buy dan Net Sell. Net Buy adalah kondisi pada saat investor asing melakukan transaksi beli lebih besar daripada transaksi jual. Net Sell adalah kondisi ketika transaksi jual lebih besar dari transaksi beli. Pada saat investor asing terus menerus melakukan Net Buy maka asing sedang masuk 
dan berinvestasi di pasar keuangan, sebaliknya jika investor asing terus-menerus melakukan aksi net sell maka investor asing hengkang dari pasar modal.

\subsection{Indeks Harga Saham Gabungan}

Indeks Harga Saham Gabungan atau Indonesia Composite Index (ICI) merupakan salah satu indeks pasar saham yang digunakan oleh Bursa Efek Indonesia. Indeks ini mencakup pergerakan harga seluruh saham biasa dan saham preferen yang tercata di BEI. Perhitungan IHSG dilakukan setiap hari yaitu setelah penutupan perdagangan. Ada tiga fungsi IHSG sebagai penanda arah pergerakan saham, mengkur tingkat keuntungan dan sebagai tolok ukur kinerja portofolio. Pergerakan IHSG dipengaruhi oleh berbagai faktor seperti tekanan global, faktor fundamenatal perusahaan, indikator ekonomi makro maupun sektoral serta kondisi sosial politik dalam negeri yang kondusif.

\subsection{Indeks LQ45}

Indeks yang mengukur performa harga saham dari 45 saham-saham yang memiliki likuiditas tinggi dan kapitalisasi pasar besar serta didukung oleh fundamental perusahaan yang baik. Indeks LQ45 merupakan 45 emiten yang telah melalui proses seleksi dengan likuiditas tinggi (LiOuid) serta memenuhi beberapa kriteria pemilihan. LQ45 adalah indeks pasar saham di Bursa Efek Indonesia yang terdiri dari 45 perusahaan dengan kriteria :

a. Perusahaan masuk dalam top 60 perusahaan dengan kapitalisasi pasar tertinggi dalam 1-2 bulan terakhir

b. Perusahaan masuk dalam top 60 perusahaan dengan nilai transaksi tertinggi di pasar reguler dalam

12 bulan terakhir

c. Tercatat di BEI selama minimal 3 bulan

d. Memiliki kondisi keuangan, propek pertumbuhan dan nilai transaksi yang tinggi.

Indeks LQ45 dihitung setiap enam bulan sekali (tiap awal Ferbruari dan Agustus) oleh divisi penelitian dan pengembangan BEI. Perusahaan yang terdaftar dalam LQ45 akan selalu berubah-ubah. Indeks LQ45 memiliki tujuan sebagai pelengkap IHSG khususnya untuk menyediakan sarana yang objektif dan terpercaya bagi analisis keuangan, manajer investasi, investor dan pemerhati pasar modal dalam memonitor pergerakan harga dari saham-saham yang aktif diperdagangkan.

\subsection{Kerangka Berpikir}

Kerangka berpikir merupakan alur atau pedoman untuk melakukan penelitian dalam rangka mendapatkan jawaban dari masalah penelitian. Bentuk kerangka pemikiran dari penelitian ini dapat dilihat pada gambar berikut ini.

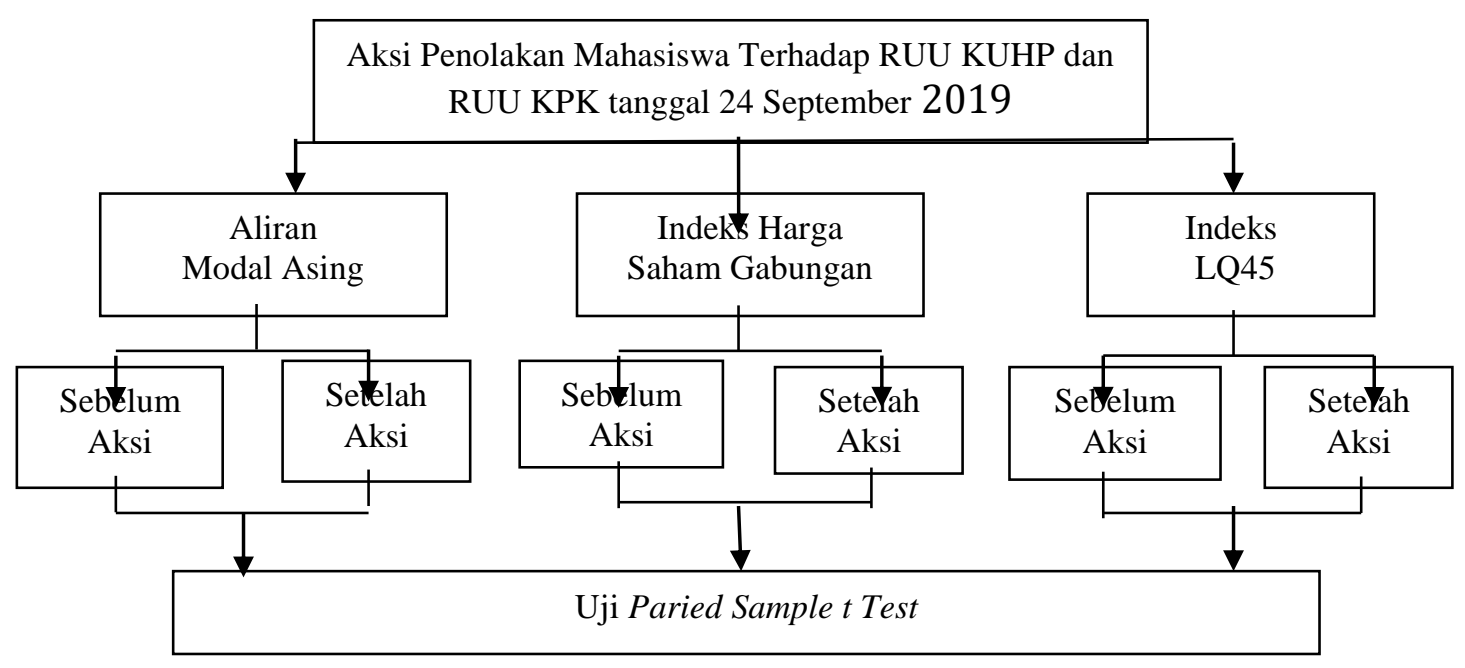

\subsection{Hipotesis Penelitian}

Hipotesis penelitian ini bertujuan untuk memberikan jawaban sementara dari rumusan masalah yang diajukan sebelumnya, maka hipotesis yang diajaukan adalah : 
$\mathrm{H}_{1}$ : Terdapat perbedaan yang signifikan pada Aliran Modal Asing di Bursa Efek Indonesia sebelum dan sesudah terjadinya aksi penolakan mahasiswa terhadap RUU KUHP dan Revisi UU KPK.

$\mathrm{H}_{2}$ : Terdapat perbedaan yang signifikan pada Indeks Harga Saham Gabungan di Bursa Efek Indonesia sebelum dan sesudah terjadinya aksi penolakan mahasiswa terhadap RUU KUHP dan Revisi UU KPK.

$\mathrm{H}_{3}$ : Terdapat perbedaan yang signifikan pada Indeks LQ45 di Bursa Efek Indonesia sebelum dan sesudah terjadinya aksi penolakan mahasiswa terhadap RUU KUHP dan Revisi UU KPK.

\section{Metode Penelitian}

\subsection{Jenis Penelitian}

Jenis penelitian yang digunakan adalah event study. Event study bertujuan untuk mengukur dampak suatu peristiwa terhadap perubahan harga saham perusahaan. Menurut Jogiyanto (2010) studi peristiwa (event study) merupakan studi yang mempelajari reaksi pasar terhadap suatu peristiwa yang informasinya dipublikasikan sebagai suatu pengumuman. Periode pengamatan disebut periode jendela (window period). Periode pengamatan selama 21 hari bursa yaitu 10 hari sebelum peristiwa (pre-event day), 1 hari saat peristiwa (event day) dan 10 hari setelah peristiwa (post event day).

\subsection{Populasi dan Sampel}

Populasi dari penelitian ini adalah semua indeks yang terdapat di Bursa Efek Indonesia yang terdiri dari 24 indeks yaitu Indeks Harga Saham Gabungan (IHSG), indeks LQ45, Indeks Sektoral, Jakarta Indeks Islamic (JII), Indeks Kompas 100, Indeks BISNIS-27, Indeks PEFINDO 25, Indeks SRI-KEHATI, Indeks IDX 30, Indeks IDX 80, Indeks IDX value 30, Indeks IDX Growth 30, Indeks BUMN 20, Indeks SMC Composite, Indeks SMC Liquid, Indeks High Dividen 20, Indeks Sminfra 18, Indeks MNC 36, Indeks Investor 33, Indeks ISSI, Indeks papan pencatatan, Indeks IDX BUMN 20, Indeks infobank 15. Metode pengambilan sampel dengan metode puposive sampling. Indeks yang menjadi sampel dalam penelitian ini adalah Indeks Harga Saham Gabungan (IHSG) dan Indeks LQ45.

\subsection{Metode Analisis Data}

\subsubsection{Statistik Deskriptif}

Uji statistik deskriptif adalah uji statistik dengan cara mendeskripsikan data yang digunakan dalam penelitian dalam bentuk tabel, maupun grafik. Dalam penelitian ini, statistik deskriptif meliputi nilai minimum, maksimum dan rata-rata dari data aliran modal asing, Indeks Harga Saham Gabungan dan Indeks LQ45 sebelum dan setelah terjadinya aksi penolakan mahasiswa terhadap RUU KUHP dan RUU KPK.

\subsubsection{Uji Normalitas}

Uji normalitas dilakukan untuk mengetahui apakah data yang digunakan dalam suatu penelitian berdistribusi normal atau tidak. Uji normalitas yang digunakan adalah uji Kolmogorov Smirnov dengan tingkat signifikansi $\alpha=0,05$. Jika nilai signifikansi $>0,05$ maka data berdistribusi secara normal, sebaliknya jika nilai signifikansi $<0,05$ maka data tidak berdistribusi normal.

\subsubsection{Uji Paired Sample T-Test}

Uji Paired Sample T Test bertujuan untuk mengetahui ada tidaknya perbedaan rata-rata antara dua sampel yang berpasangan dengan asumsi data berdistribusi normal. Sampel berpasangan berasal dari subjek yang sama namun setiap variabel diambil pada saat situasi dan keadaan yang berbeda. Hasil uji Paired Sample T Test ditentukan dari nilai signifikansinya. Jika nilai signifikansi (2-tailed) $<0,05$ artinya terdapat perbedaan yang signifikan sebelum dan setelah terjadinya aksi penolakan mahasiswa. Jika nilai signifikansi (2-tailed) > 0,05 artinya tidak terdapat perbedaan yang signifikan sebelum dan setelah terjadinya aksi penolakan mahasiswa. Untuk data yang tidak berdistribusi normal digunakan uji non parametrik yaitu Wilcoson Signed Rank t-test.

\section{Hasil dan Pembahasan}

\subsection{Statistik Deskriptif Aliran Modal Asing}

Aksi mahasiswa atas penolakan RUU KUHP dan Revisi UU KPK yang terjadi tanggal 24 September 2019 berdampak negatif terhadap aliran modal asing di pasar modal Indonesia. Hal tersebut ditandai dengan adanya aksi jual bersih (net sell) yang dilakukan investor asing di pasar 
reguler. Berdasarkan data yang diperoleh dari perdagangan di Bursa Efek Indonesia menunjukkan bahwa aliran modal asing di Pasar Reguler daalam kurun waktu 21 hari perdagangan dapat dilihat dari tabel berikut:

Tabel 4.1. Aliran Modal Investor Asing di Pasar Reguler

\begin{tabular}{|c|c|c|c|c|}
\hline Hari & Sebelum aksi (10-t) & Saat aksi (t) & Hari & Setelah aksi $(t+1)$ \\
\hline $10-\mathrm{t}$ & Rp. 185,64 miliar (NS) & $\begin{array}{l}\text { Rp. } 773,17 \text { miliar } \\
\text { (NS) }\end{array}$ & $10+\mathrm{t}$ & Rp. 185,81 miliar (NS) \\
\hline $9-\mathrm{t}$ & Rp. 833,82 miliar (NS) & & $9+\mathrm{t}$ & Rp. 144,8 miliar (NB) \\
\hline $8-\mathrm{t}$ & Rp. 596,51 miliar (NS) & & $8+\mathrm{t}$ & Rp. 474,79 miliar (NB) \\
\hline $7-\mathrm{t}$ & Rp. 338,06 miliar (NS) & & $7+t$ & Rp. 792,38 miliar (NS) \\
\hline $6-\mathrm{t}$ & Rp. 585,67 miliar (NS) & & $6+t$ & Rp. 788,97 miliar (NB) \\
\hline $5-\mathrm{t}$ & Rp. 558,91 miliar (NS) & & $5+\mathrm{t}$ & Rp. 607,20 miliar (NS) \\
\hline $4-\mathrm{t}$ & Rp. 135,13 miliar (NS) & & $4+\mathrm{t}$ & Rp. 68,91 miliar (NS) \\
\hline $3-\mathrm{t}$ & Rp. 494,15 miliar (NS) & & $3+\mathrm{t}$ & Rp. 338,59 milair (NS) \\
\hline $2-\mathrm{t}$ & Rp. 237,89 miliar (NB) & & $2+\mathrm{t}$ & Rp. 175,54 miliar (NB) \\
\hline $1-\mathrm{t}$ & Rp. 185,73 miliar (NS) & & $1+\mathrm{t}$ & Rp. 769,74 miliar (NS) \\
\hline
\end{tabular}

Sumber :https://market.bisnis.com (Bursa Efek Indonesia)

Dari Tabel 4.1 diatas, menunjukkan adanya reaksi pelaku pasar terutama dari investor asing pada saat terjadinya aksi penolakan mahasiswa terhadap RUU KUHP dan RUU KPK pada tanggal 24 September 2019. Reaksi pasar tersebut ditandai dengan adanya aksi jual bersih (Net Sell) di pasar reguler. Aksi net sell menunjukkan bahwa investor asing melepaskan saham-sahamnya dari pasar keuangan. Aksi investor asing di pasar reguler dalam periode pre-event day (10 hari sebelum aksi penolakan mahasiswa) menunjukkan bahwa investor asing lebih memilih mundur dari pasar modal dengan melakukan aksi jual bersih selama 9 hari perdagangan dan aksi beli (net buy) hanya satu hari saja. Pada saat aksi penolakan berlangsung pada tanggal 24 September 2019, investor asing membukukan aksi jual bersih (net sell) di pasar reguler mencapai Rp. 773,17 miliar. Pasca aksi penolakan mahasiswa (post event day), investor asing dominan melakukan aksi jual bersih (net sell) 6 hari perdagangan dan aksi beli (net buy) 4 hari bursa.

\subsection{Deskripsi Pergerakan IHSG}

Aksi penolakan mahasiswa terkait pengesahan RUU KPK dan RUU KUHP juga berdampak negatif tehadap kinerja Indeks Harga Saham Gabungan di pasar saham. Hal ini direfleksikan dari penurunan laju IHSG. Untuk melihat pergerakan IHSG di pasar bursa selama 21 hari dapat dilihat dalam tabel berikut.

Tabel 4.2. Pergerakan IHSG

\begin{tabular}{|l|l|l|l|l|}
\hline Hari & Sebelum aksi & Saat aksi & Hari & Setelah aksi \\
\hline $10-\mathrm{t}$ & 6206,199 & 6137,608 & $10+\mathrm{t}$ & 6039,601 \\
\hline $9-\mathrm{t}$ & 6231,473 & & $9+\mathrm{t}$ & 6000,582 \\
\hline $8-\mathrm{t}$ & 6244,479 & & $8+\mathrm{t}$ & 6061,252 \\
\hline $7-\mathrm{t}$ & 6276,633 & & $7+\mathrm{t}$ & 6038,529 \\
\hline $6-\mathrm{t}$ & 6236,690 & & $6+\mathrm{t}$ & 6055,425 \\
\hline $5-\mathrm{t}$ & 6219,843 & & $5+\mathrm{t}$ & 6138,250 \\
\hline $4-\mathrm{t}$ & 6334,843 & & $4+\mathrm{t}$ & 6169,102 \\
\hline $3-\mathrm{t}$ & 6342,174 & & $3+\mathrm{t}$ & 6196,889 \\
\hline $2-\mathrm{t}$ & 6381,954 & & $2+\mathrm{t}$ & 6230,334 \\
\hline $1-\mathrm{t}$ & 6336,673 & & $1+\mathrm{t}$ & 6146,404 \\
\hline Mean & 6281,096 & 6137,608 & Mean & 6107,637 \\
\hline
\end{tabular}


Dari tabel 4.2 diatas, maka pergerakan Indeks Harga Saham Gabungan selama 21 hari bursa dapat diuraikan sebagai berikut :

a. Nilai IHSG di pasar modal sebelum terjadinya peristiwa cenderung mengalami penurunan setiap harinya (selama 10 hari). Nilai rata-rata IHSG selama 10 hari adalah 6.281,096, nilai IHSG yang terendah dalam 10 hari berada di level 6.206,199 (10-t) dan nilai tertinggi IHSG berada pada posisi 6.381,954 (2-t).

b. Pada tanggal 24 September 2019 posisi IHSG berada di zona merah dan ditutup anjlok pada level $6.137,608$.

c. Nilai IHSG setelah aksi demo mahasiswa dalam 10 hari juga cenderung mengalami penurunan. Nilai rata-rata IHSG selama 10 hari adalah 6.107,637 dengan nilai terendah berada pada level $6.000,582$ pada hari ke $(9+\mathrm{t})$ dan nilai tertinggi berada pada level $6.230,334$ yaitu pada hari $(2+\mathrm{t})$.

\subsection{Pergerakan Indeks LQ45}

Pergerakan saham perusahaan yang tergabung dalam indeks LQ45 menjadi sorotan terutama pada saat terjadinya aksi demonstrasi mahasiswa dan juga setelah aksi demonstrasi. Dalam kurun waktu 21 hari saham perusahaan LQ45 mengalami pergerakan yang fluktuatif. Sebelum terjadinya aksi demonstrasi harga saham LQ45 dominan mengalami kenaikan, sementara pada saat demonstrasi berlangsung harga saham LQ45 mengalami penurunan yang cukup signifikan. Setelah aksi demonstrasi selesai ternyata harga saham perusahaan LQ45 justru mengalami penurunan yang cukup tajam. Berikut ini adalah hasil laju indeks LQ45 selama 21 hari bursa.

Tabel 4.3. Pergerakan Indeks LQ45

\begin{tabular}{|l|l|l|l|l|}
\hline Hari & Sebelum aksi & Saat aksi & Hari & Setelah aksi \\
\hline $10-\mathrm{t}$ & 976,777 & 961,532 & $10+\mathrm{t}$ & 937,994 \\
\hline $9-\mathrm{t}$ & 980,766 & & $9+\mathrm{t}$ & 931,036 \\
\hline $8-\mathrm{t}$ & 982,798 & & $8+\mathrm{t}$ & 942,638 \\
\hline $7-\mathrm{t}$ & 991,842 & & $7+\mathrm{t}$ & 935,426 \\
\hline $6-\mathrm{t}$ & 985,924 & & $6+\mathrm{t}$ & 941,742 \\
\hline $5-\mathrm{t}$ & 983,248 & & $5+\mathrm{t}$ & 960,154 \\
\hline $4-\mathrm{t}$ & 992,249 & & $4+\mathrm{t}$ & 968,147 \\
\hline $3-\mathrm{t}$ & 992,620 & & $3+\mathrm{t}$ & 972,447 \\
\hline $2-\mathrm{t}$ & 1002,547 & & $2+\mathrm{t}$ & 979,123 \\
\hline $1-\mathrm{t}$ & 992,861 & & $1+\mathrm{t}$ & 961,126 \\
\hline Mean & 988,163 & 961,532 & Mean & 952,983 \\
\hline
\end{tabular}

Sumber : www.duniainvestasi.com (data diolah)

Dari tabel 4.3 diatas, menunjukkan pergerakan indeks LQ45 dalam kurun waktu 21 hari bursa dapat diuraikan sebagai berikut :

a. Sebelum aksi terjadi dalam kurun waktu 10 hari indeks LQ45 cenderung berfluktuasi setiap harinya. Nilai rata-rata indeks LQ45 berada di level 988,163 dengan nilai terendah menyentuh angka 976,777 yaitu pada (10-t) sehari sebelum aksi demo berlangsung dan nilai tertinggi berada di level 1.002,547 yaitu pada hari ke (2-t).

b. Pada saat aksi demo terjadi tepatnya tanggal 24 September 2019 nilai indeks LQ45 berada di zona merah pada posisi 961,532 .

c. Setelah aksi terjadi laju indeks LQ 45 terus mengalami penurunan yang semakin tajam. Nilai rata-rata indeks LQ45 berada pada posisi 952,983 dengan nilai terendah berada di level 931,036 berada pada hari $(9+\mathrm{t})$ dan nilai tertinggi di posisi 979,123 pada hari ke $(2+\mathrm{t})$.

\subsection{Hasil Uji Normalitas}

Hasil uji normalitas dalam penelitian ini dilakukan dengan uji One Sample Kolmogorov Smirnov. Uji normalitas ini bertujuan untuk melihat apakah data yang digunakan dalam penelitian ini berdistribusi normal atau tidak. Hasil uji normalitas dari data Indeks IHSG, Indeks LQ45 dan Aliran Modal Asing dalam penelitian ini dapat dilihat pada tabel berikut ini. 
Tabel 4.4 : Hasil Uji Normalitas

\begin{tabular}{|l|r|r|r|r|}
\hline & & \multicolumn{1}{|c|}{$\begin{array}{c}\text { Indeks } \\
\text { IHSG }\end{array}$} & \multicolumn{1}{c|}{$\begin{array}{c}\text { Indeks } \\
\text { LQ45 }\end{array}$} & \multicolumn{1}{c|}{$\begin{array}{c}\text { Modal } \\
\text { Asing }\end{array}$} \\
\hline $\mathrm{N}$ & & 21 & 21 & 21 \\
\hline $\begin{array}{l}\text { Kolmogorov-Smirnov } \\
\text { Z }\end{array}$ &, 547 &, 659 &, 572 \\
\hline Asymp. Sig. (2-tailed) & &, 925 &, 778 &, 899 \\
\hline
\end{tabular}

Sumber : hasil Penelitian, 2019 (data diolah)

Dari tabel uji normalitas pada Tabel 4.4 menunjukkan bahwa data Indeks IHSG, data Indeks LQ45 serta data Aliran Modal Asing masing-masing memiliki nilai Asymp. Signifikansi diatas 0,05. Hasil ini membuktikan bahwa semua data yang digunakan dalam penelitian ini telah berdistribusi secara normal.

\subsection{Hasil Uji Hipotesis}

Uji hipotesis dalam penelitian ini dilakukan dengan menggunakan uji Paried Sample t Test. Uji ini bertujuan untuk melihat apakah terdapat perbedaan yang signifikan pada nilai Indeks Harga Saham Gabungan, Indeks LQ45 dan Aliran Modal Asing di Bursa Efek indonesia baik sebelum dan sesudah terjadinya aksi penolakan mahasiswa terhadap RUU KUHP dan RUU KPK pada tanggal 24 September 2019.

\subsubsection{Hasil Uji Paried Sample t Test Aliran Modal Asing}

Untuk mengetahui apakah terdapat perbedaan aliran modal asing di pasar modal sebelum dan setelah aksi penolakan mahasiswa terhadap RUU KUHP dan RUU KPK pada tanggal 24 September 2019 dapat dilihat dari hasil uji Paried Sample t Test berikut ini. 
Tabel 4.5 : Hasil uji Paired Samples Test Aliran Modal Asing

\begin{tabular}{|c|c|c|c|c|c|c|c|c|c|}
\hline & \multicolumn{5}{|c|}{ Paired Differences } & \multirow[b]{3}{*}{$\mathrm{t}$} & \multirow[b]{3}{*}{ df } & \multirow{3}{*}{$\begin{array}{c}\text { Sig. } \\
(2- \\
\text { tailed })\end{array}$} \\
\hline & & \multirow[b]{2}{*}{ Mean } & \multirow{2}{*}{$\begin{array}{c}\text { Std. } \\
\text { Deviatio } \\
\text { n }\end{array}$} & \multirow{2}{*}{$\begin{array}{l}\text { Std. } \\
\text { Error } \\
\text { Mean }\end{array}$} & \multicolumn{2}{|c|}{$\begin{array}{l}95 \% \text { Confidence } \\
\text { Interval of the } \\
\text { Difference }\end{array}$} & & & \\
\hline & & & & & Lower & Upper & & & \\
\hline $\begin{array}{l}\text { Pair } \\
1\end{array}$ & \begin{tabular}{|l|} 
Modal \\
Asing \\
Sebelum - \\
Modal \\
Asing \\
Setelah
\end{tabular} & 249,720 & 662,796 & $\begin{array}{r}209,59 \\
4\end{array}$ & $-723,856$ & 224,416 & $-1,191$ & 9 & ,264 \\
\hline
\end{tabular}

Sumber : Hasil Penelitian, 2019 (data diolah)

Berdasarkan hasil uji Paired Samples Test pada tabel 4.5 tersebut, menunjukkan bahwa nilai Sig. (2-tailed) sebesar 0,264 >0,05. Hasil ini membuktikan tidak terdapat perbedaan secara signifikan atas aliran modal asing di pasar modal baik sebelum dan setelah aksi penolakan mahasiswa terhadap RUU KUHP dan RUU KPK pada tanggal 24 September 2019.

\subsubsection{Hasil Uji Paried Sample t Test Indeks Harga Saham Gabungan}

Untuk melihat apakah terdapat perbedaan Indeks Harga Saham Gabungan di pasar modal sebelum dan setelah aksi penolakan mahasiswa terhadap RUU KUHP dan RUU KPK pada tanggal 24 September 2019 dapat dilihat dari hasil uji Paried Sample t Test berikut ini.:

Tabel 4.6 : Hasil uji Paired Samples Test Indeks Harga Saham Gabungan

\begin{tabular}{|c|c|c|c|c|c|c|c|c|c|}
\hline & \multicolumn{5}{|c|}{ Paired Differences } & \multirow[b]{3}{*}{$\mathrm{t}$} & \multirow[b]{3}{*}{$\mathrm{df}$} & \multirow{3}{*}{$\begin{array}{l}\text { Sig. (2- } \\
\text { tailed) }\end{array}$} \\
\hline & & \multirow[b]{2}{*}{ Mean } & \multirow{2}{*}{$\begin{array}{c}\text { Std. } \\
\text { Deviatio } \\
\text { n }\end{array}$} & \multirow{2}{*}{$\begin{array}{l}\text { Std. } \\
\text { Error } \\
\text { Mean }\end{array}$} & \multicolumn{2}{|c|}{$\begin{array}{l}95 \% \text { Confidence } \\
\text { Interval of the } \\
\text { Difference }\end{array}$} & & & \\
\hline & & & & & Lower & Upper & & & \\
\hline Pair 1 & $\begin{array}{l}\text { IHSG } \\
\text { Sebelum } \\
- \text { IHSG } \\
\text { Setelah }\end{array}$ & 173,459 & 44,38850 & $\begin{array}{r}14,036 \\
8\end{array}$ & 141,705 & 205,21292 & $\begin{array}{r}12,35 \\
7\end{array}$ & 9 & 000 \\
\hline
\end{tabular}

Sumber : Hasil Penelitian, 2019 (data diolah)

Dari Tabel 4.6, dapat diketahui bahwa hasil uji Paired Samples Test menunjukkan bahwa nilai Sig. (2-tailed) sebesar 0,000 >0,05. Hasil ini membuktikan terdapat perbedaan yang signifikan pada Indeks Harga Saham Gabungan di Bursa Efek Indonesia baik sebelum dan setelah aksi penolakan mahasiswa terhadap RUU KUHP dan RUU KPK pada tanggal 24 September 2019.

\subsubsection{Hasil uji Paired Samples Test Indeks LQ45}

Untuk mengetahui apakah terdapat perbedaan Indeks LQ45 di pasar modal sebelum dan setelah aksi penolakan mahasiswa terhadap RUU KUHP dan RUU KPK pada tanggal 24 September 2019 dapat dilihat dari hasil uji Paried Sample t Test berikut ini. 
Tabel 4.7 : Hasil uji Paired Samples Test Indeks LQ 45

\begin{tabular}{|c|c|c|c|c|c|c|c|c|c|}
\hline & \multicolumn{5}{|c|}{ Paired Differences } & \multirow[b]{3}{*}{$\mathrm{t}$} & \multirow[b]{3}{*}{ Df } & \multirow{3}{*}{$\begin{array}{l}\text { Sig. } \\
(2- \\
\text { tailed) }\end{array}$} \\
\hline & & \multirow[b]{2}{*}{ Mean } & \multirow{2}{*}{$\begin{array}{c}\text { Std. } \\
\text { Deviatio } \\
\mathrm{n}\end{array}$} & \multirow{2}{*}{$\begin{array}{l}\text { Std. } \\
\text { Error } \\
\text { Mean }\end{array}$} & \multicolumn{2}{|c|}{$\begin{array}{l}\text { 95\% Confidence } \\
\text { Interval of the } \\
\text { Difference }\end{array}$} & & & \\
\hline & & & & & Lower & Upper & & & \\
\hline $\begin{array}{l}\text { Pair } \\
1\end{array}$ & $\begin{array}{l}\text { Indeks LQ45 } \\
\text { Sebelum - } \\
\text { Indeks LQ45 } \\
\text { Setelah }\end{array}$ & 35,1799 & 12,58554 & $\begin{array}{r}3,9799 \\
0\end{array}$ & 26,176 & 44,183 & 8,839 & 9 & ,000 \\
\hline
\end{tabular}

Sumber : Hasil Penelitian, 2019 (data diolah)

Dari hasil uji Paired Samples Test Indeks LQ 45 dalam Tabel 4.7, menunjukkan bahwa nilai Sig. (2-tailed) sebesar 0,000 >0,05. Hasil ini menunjukkan bahwa terdapat perbedaan yang signifikan atas nilai Indeks LQ45 di Bursa Efek Indonesia baik sebelum dan setelah aksi penolakan mahasiswa terhadap RUU KUHP dan RUU KPK pada tanggal 24 September 2019.

\subsection{Pembahasan Hasil Penelitian}

\subsubsection{Pergerakan Aliran Modal Asing}

Dari hasil uji Paired Samples Test menunjukkan tidak terdapat perbedaan Aliran Modal Asing di Bursa Efek indonesia baik sebelum dan sesudah aksi penolakan mahasiswa terhadap RUU KUHP dan Revisi UU KPK. Hasil tersebut dapat dibuktikan dari nilai Sig. (2-tailed) sebesar 0,264 $>0,05$. Aliran modal asing di Bursa Efek Indonesia sebelum tanggal 24 September 2019 dengan kata lain sebelum terjadinya aksi penolakan mahasiswa terhadap RUU KUHP dan RUU KPK ternyata sudah menyusut karena investor asing banyak melakukan aksi jual bersih (Net Sell) di sepanjang awal September 2019. Penyebab aliran modal asing menyusut di pasar modal salah satunya dipengaruhi aspek global dan aspek. Dari aspek global berasal dari perang dagang antara Amerika Serikat (AS) dengan China. Aspek domestik berasal dari kerusuhan yang terjadi di Papua telah menggoyang iklim investasi di Indonesia. Penyebab investor menarik modalnya dari Indonesia dikarenakan adanya persepsi negatif dari investor terhadap kondisi keamanan dalam negeria.

Pasca aksi penolakan mahasiswa, ternyata aliran modal asing dari Indonesia banyak yang keluar dari pasar saham. Sepanjang aksi demontrasi yang terjadi sejak tanggal 24 September 2019 hingga tanggal 8 Oktober 2019, perdagangan saham di pasar modal mayoritas diwarnai aksi jual bersih oleh investor asing. Banyaknya dana asing yang keluar dari Indonesia terjadi karena kondisi politik dan keamanan Indonesia tidak stabil dimulai dari aksi penolakan hasil Pilpres yang berujung rusuh, Kerusuhan Papua dan berlanjut dengan aksi penolakan mahasiswa terhadap RUU KUHP dan RUU KPK.. Maraknya aksi demonstrasi yang berkepanjangan yang berujung pada kerusuhan dan tindakan anarkis menjadi pertimbangan investor asing menarik dananya dari Indonesia.

\subsubsection{Pergerakan Indeks Harga Saham Gabungan}

Dari hasil uji Paired Samples Test menunjukkan terdapat perbedaan yang signifikan pada Indeks Harga Saham Gabungan di Bursa Efek Indonesia baik sebelum dan setelah aksi penolakan mahasiswa terhadap RUU KUHP dan RUU KPK pada tanggal 24 September 2019. Hasil tersebut dapat dilihat dari nilai Sig. (2-tailed) sebesar 0,000 > 0,05. Indeks Harga Saham Gabungan (IHSG) terus mengalami pelemahan baik sebelum dan setelah terjadinya aksi penolakan mahasiswa. Adanya perbedaan yang signifikan pada Indeks Harga Saham Gabungan di pasar modal disebabkan 
penurunan IHSG pasca aksi penolakan cukup besar jika dibandingkan dengan penurunan IHSG sebelum aksi penolakan mahasiswa. Salah satu pemicu melemahnya IHSG di pasar modal sepanjang September 2019 karena investor asing terus menerus melakukan aksi jual bersih (net sell).

Sebelum aksi penolakan mahasiswa terhadap RUU KUHP dan RUU KPK, laju IHSG di pasar modal berada pada zona merah. Hal ini dikarenakan adanya perang dagang Amerika Serikat dengan China. Laju indeks IHSG semakin terpuruk akibat aksi demo mahasiswa yang mengangkat isu sensitif. Hal ini semakin jelas terlihat dari bursa saham utama di kawasan Asia kompak bergerak di zona hijau kecuali IHSG berada di zona merah. Meskipun aksi demo mahasiswa terkait Revisi UU KPK dan RUU KUHP belum mengganggu kegiatan perekonomian, namun aksi tersebut sudah mengganggu iklim investasi di Indonesia. Kericuhan demonstrasi yang terjadi dibeberapa wilayah Indonesia justru membuat kondisi pasar keuanganan nasional semakin terpuruk. Pelaku pasar terutama investor asing semakin khawatir terhadap kondisi politik yang kurang kondusif pasca demo mahasiswa yang berakhir ricuh. Dari uraian tersebut dapat disimpulkan bahwa penurunan IHSG di pasar modal sebelum aksi penolakan mahasiswa disebabkan kondisi global dan juga dampak dari kerusahan yang etrjadi di Papua. Aksi penolakan mahasiswa terhadap RUU KUHP dan Revisi UU KPK menyebabkan penurunan IHSG di pasar keuangan semakin terpuruk, hal ini dikarenakan aksi tersebut berakhir dengan pengrusakan dan tindakan anarkis.

\subsubsection{Pergerakan Indeks LQ45}

Dari hasil uji Paired Samples Test menunjukkan terdapat perbedaan yang signifikan atas nilai Indeks LQ45 di Bursa Efek Indonesia baik sebelum dan setelah aksi penolakan mahasiswa terhadap RUU KUHP dan RUU KPK pada tanggal 24 September 2019. Hal ini dapat dilihat dari hasil uji Paired Samples Test yang memiliki nilai Sig. (2-tailed) sebesar 0,000 >0,05. Sebelum dan setelah terjadinya aksi penolakan mahasiswa terhadap RUU KUHP dan RUU KPK laju indeks LQ45 di pasar modal dalam kurun waktu 10 hari berfluktiatif. Hal ini menandakan bahwa indeks LQ45 berada di zona hijau maupun di zona merah. Faktor yang menyebabkan adanya perbedaan yang signifikan pada nilai Indeks LQ45 di Bursa Efek Indonesia dalam penelitian ini disebabkan penurunan indeks LQ45 sebelum aksi penolakan hanya terkoreksi tipis sementara penurunan indeks LQ45 setelah aksi penolakan mengalami penurunan yang besar.

Sebelum aksi penolakan mahasiswa terjadi rata-rata indeks LQ45 dalam kurun waktu 10 hari bursa sebesar 988,163 point lebih besar jika dibandingkan dengan nilai rata-rata indeks LQ45 yaitu 952,983 setelah aksi penolakan dalam kurun waktu 10 hari juga. Dari uraian tersebut dapat disimpulkan bahwa saham-saham yang masuk dalam kategori LQ45 mengalami penurunan yang signifikan setelah aksi penolakan mahasiswa terjadi. Adanya penurunan laju indeks LQ45 setelah aksi mahasiswa mengindikasikan bahwa pelaku pasar terutama investoar asing merasa cemas dan khawatir dengan kondisi politik dalam negeri. Menurunnya kepercayaan investor asing untuk berinvestasi di Indonesia ditandai dengan banyaknya aliran modal asing yang kelaur dari pasar modal.

\section{Simpulan dan Saran \\ 5.1. Simpulan}

Dari hasil penelitian dan pemabahasan tersebut, maka kesimpulan dari penelitian ini adalah sebagai berikut:

1. Tidak terdapat perbedaan yang signifikan pada Aliran Modal Asing di Bursa Efek Indonesia baik sebelum dan sesudah terjadinya aksi penolakan mahasiswa terhadap RUU KUHP dan Revisi UU KPK. Hal ini dapat dilihat dari nilai signifikansi uji Paired Samples Test sebesar $0,264>0,05$.

2. Terdapat perbedaan yang signifikan pada Indeks Harga Saham Gabungan di Bursa Efek Indonesia sebelum dan sesudah terjadinya aksi penolakan mahasiswa terhadap RUU KUHP dan Revisi UU KPK. Hal ini dapat dilihat dari nilai signifikansi uji Paired Samples Test sebesar $0,000<0,05$. 
3. Terdapat perbedaan yang signifikan pada Indeks LQ45 di Bursa Efek Indonesia sebelum dan sesudah terjadinya aksi penolakan mahasiswa terhadap RUU KUHP dan Revisi UU KPK. Hal ini dapat dilihat dari nilai signifikansi uji Paired Samples Test sebesar 0,000 <0,05.

\subsection{Saran}

Dari hasil penelitian yang diperoleh dalam penelitian ini, maka saran yang diberikan adalah sebagai berikut :

1. Bagi mahasiswa

Bagi mahasiswa yang hendak menyampaikan aspirasinya melalui aksi demonstrasi, sebaiknya melakukan aksinya secara aman dan tertib serta mematuhi peraturan yang ada dan menghindari terjadinya tindakan anarkisme dan pengrusakan fasilitas umum selama aksi demonatrsi berlangsung.

2. Bagi pemerintah

Kondisi pasar modal akan selalu berfluktuasi dan tergantung pada berbagai sentimen yang dapat mengganggu kenyamanan investor dalam berinvestasi. Oleh karena itu pemerintah senantiasa dapat menjaga kondisi politik dan ekonomi dalam negeri tetap kondusif dan stabil sehingga tidak mengganggu iklim investasi.

\section{Daftar Pustaka}

Ghozali, Imam, 2016. Aplikasi Analisis Multivariate dengan Program SPSS, Badan Penerbit Universitas Diponegoro, Semarang.

Jogiyanto, Hartono. 2010. Teori Portofolio dan Analisis Investasi. Edisi Kedelapan, BPFE, Yogyakarta.

Yuniarti dan Sujana, 2016. Reaksi Pasar Modal Terhadap Pencalonan Jokowi Menjadi Presiden Republik Indonesia. E-Jurnal Akuntansi Universitas Udayana. 16(2): 951-977

https://www.duniainvestasi.com. Idx: Jakarta Composite Index (IHSG).

https://www.duniainvestasi.com. Summary of idx : LQ45 Index,

https://market.bisnis.com (Ringkasan Perdagangan Saham oleh Investor Asing 